\title{
Nuevos documentos hebraico-aljamiados de Aragón (1) Fragmentos de un registro contable de pagos de la aljama de Tarazona
}

\author{
Javier CASTAÑO * \\ Instituto de Filología - CSIC, Madrid
}

Poco antes de su desaparición, José L. Lacave había proyectado llevar a cabo una recopilación de los textos documentales medievales aljamiados y hebreos dispersos en los archivos del reino de Aragón y de la Corona de Castilla, un proyecto al que él mismo había contribuido con aportaciones fundamentales. Entre los papeles de su legado depositado en el CSIC se encuentran algunas transcripciones de documentos medievales inéditos, en diverso estado de finalización, que saldrán próximamente a la luz bajo su nombre, una vez realizados los arreglos necesarios. Como previa contribución modesta a su legado científico, presento una nueva serie de textos hebraico-aljamiados bajomedievales de procedencia aragonesa que él no llegó a conocer, y cuyo contenido coincide con una de las líneas de investigación a la que dedicó prolongados esfuerzos, en su afán por ofrecer nuevos materiales de estudio a historiadores y filólogos ${ }^{1}$.

\footnotetext{
* castano@filol.csic.es

1 Por razones editoriales, se presenta aquí la primera parte del trabajo, cuya continuación será publicada en el próximo fascículo de Sefarad.
}

Sefarad 64 (2004) págs. 315-340

(c) CSIC

ISSN 037-0894 
UN REGISTRO CONTABLE DE PAGOS DE LA ALJAMA DE TARAZONA (1406 Y 1407) EN LA COLECCIÓN YAHUDA

En 1969 se incorporaron a las colecciones de la Jewish National and University Library de Jerusalén diversos materiales manuscritos que habían sido propiedad del orientalista, biblista y coleccionista Abraham S. Yahuda, tras una larga batalla legal que comienza a su muerte en 1951 por la resistencia de su viuda a cumplir el último deseo del erudito. Pese a haberse desprendido de valiosos manuscritos islámicos a su llegada a los Estados Unidos en 1940 (vendidos a la biblioteca de Princeton, a excepción de un grupo de manuscritos de contenido médico, que lo fueron a la National Library of Medicine en Bethesda, Md.), Yahuda conserva hasta su desaparición el resto de una valiosa colección, en la que se incluyen varios lotes con escritos teológicos de I. Newton (adquiridos en dura pugna, no siempre leal, con J. M. Keynes, tras la subasta en 1936 en Sotheby's), lotes que intentaría vender infructuosamente a varias bibliotecas universitarias norteamericanas.

Dentro de su fondo de manuscritos hebreos se encuentran catalogados unos restos fragmentarios -sin determinación de procedencia geográfica (exceptuando la general de Aragón), ni de datación cronológica- de un cuaderno en papel que ya había sido correctamente asignado a un «register of expenditures of a Jewish community in Aragon» ${ }^{2}$, en romance aragonés y caracteres hebreos ${ }^{3}$. No está claro cómo, ni cuándo, llegaron dichos fragmentos a manos del que sería efímero "primer catedrático judío de la España contemporánea», que figura entre los más importantes coleccionistas de manuscritos de la primera mitad del siglo XX. Nacido en la Jerusalén otomana y de nacionalidad británica, Yahuda completa su formación académica en Heidelberg y Berlín, viajando a España en 1913 por primera vez,

2 En R. Weiser (ed.), Books from Sefarad (Jerusalem 1992) n. ${ }^{\circ}$ 86, págs. 150151.

3 JNUL, Ms. YAH Heb. 242. Agradezco a Rivka Plesser, directora de la sección de manuscritos, las facilidades dadas para la consulta del manuscrito y el permiso para su publicación. 
y retornando un año después para establecerse en Madrid. En 1915, y gracias a las gestiones y esfuerzos de Fidel Fita y Julián Ribera, recibe una cátedra de hebreo rabínico en la Universidad Central que, junto con el Centro de Estudios Históricos de la calle Almagro, serán los dos lugares donde imparta su docencia. Es conocido su interés particular por la recuperación del patrimonio manuscrito y bibliográfico hispano-judío, y sabemos que realiza viajes por todo el país, incluyendo Aragón ${ }^{4}$. Podría ser en uno de esos viajes en donde adquiere los fragmentos estudiados aquí. Ostenta su cátedra hasta 1920 , año en que abandona y se establece en Londres, cuya bulliciosa vida social e intelectual le va a resarcir del abrupto final madrileño. Parece que vuelve fugazmente en dos ocasiones a España en plena república y antes de los inicios de la guerra civil.

El estímulo intelectual londinense, y el de sus casas de subasta, decaen ante el inicio de la nueva guerra mundial, y en 1940, al igual que lo hacen otros intelectuales judíos europeos, decide instalarse en Estados Unidos, no sin antes haber escrito una dura crítica al autor de Der Mann Moses und die monotheistische Religion, obra publicada en 1939. Ya desde su marcha de Madrid, y hasta su muerte en 1951, Yahuda asistirá como atento espectador desde la distancia, lamentándose en sus memorias y cartas del olvido oficial de lo que consideraba que había sido su aportación fundamental al inicio de los estudios judíos en España.

El fragmento manuscrito está compuesto por tres folios de $290 \mathrm{x}$ $200 \mathrm{~mm}$, escritos por ambas caras en escritura hebrea cursiva realizada por una misma mano. El estado de conservación de dos de los folios está muy perjudicado por la humedad, dificultando su lec-

\footnotetext{
4 Un perfil biográfico con referencias tanto a su intercambio epistolar con Rafael Cansinos-Assens, como a sus propias memorias, en las que reivindica un protagonismo en los inicios de la vida judía organizada en la España contemporánea, registrando diversas anécdotas que muestran ese interés por manuscritos medievales y libros hebreos antiguos, en J. ISRAEL GARZÓN, «El primer catedrático judío de la España contemporánea: Abraham Yahuda», Raíces 19 (1994) págs. 29-39: pág. 29, y A. S. YAHUDA, «Mis recuerdos de España» (traducción del hebreo de Isaac Gershon), en ibid., págs. 40-51: págs. 50-51.
} 
tura. Cada una de las páginas recoge las entradas de pagos de la comunidad judía de Tarazona, 42 en total, que van encabezadas en el margen (al igual que en los libros de contabilidad coetáneos) derecho por la cantidad, expresada en florines o en sueldos y dineros, y la especificación del cargo realizado. Al final de cada página se incluye una cantidad global que supone la suma de todos los cargos incluidos en ella. De esta manera, los tres folios resultan independientes, y aunque todas las entradas se refieren a cargos que se pueden fechar entre 1406 y 1407, no se puede afirmar con absoluta certeza que los tres folios conservados sean sucesivos. No conocemos el procedimiento de anotación de los cargos del registro, ya que o bien no se anotan en el momento en el que se hacen efectivos los pagos, o bien éstos se realizan después del momento debido. Así, en un mismo folio aparecen, sucesivamente anotados: el pago de un censal vendido al concejo y cuyo censo anual debía hacerse efectivo en Santa María de agosto ${ }^{5}$ (n. $\left.{ }^{0} 16\right)$; las albricias pagadas al procurador que informa del nacimiento del infante Martín, nacido en Navidad de 1406, aunque la noticia se comunica a las ciudades semanas más tarde (n. ${ }^{\circ} 23$ ); y el cargo del pago, en parte realizado por escote, de las «cuatro especies» de plantas utilizadas en la fiesta de Sucot, celebrada a comienzos del otoño. Claro que este pago puede haber quedado registrado con posterioridad.

La numeración moderna de los folios realizada por los catalogadores aparece invertida, ya que comienza por la cara del folio cuyo margen izquierdo es el que corresponde al de encuadernación. Sin embargo, el orden de folios en un manuscrito hebreo precisaría de la encuadernación por el margen derecho. Teniendo esto en cuenta, se debería numerar en dirección contraria a la realizada, de manera que el folio 1a correspondería en realidad a $3 b$, y así sucesivamente. La evolución cronológica de determinados asuntos tratados en el texto a lo largo de diversos cargos avalaría esta propuesta.

5 Dicho censo se cobraba anualmente desde 1391 en Santa María de agosto; $c f r$. M. A. Motis Dolader, Los judios de Tarazona en el siglo XIV. II. Colección documental (Tarazona 2003) págs. 326-327. 
El contenido de algunos cargos registrados permite fijar su datación a lo largo de 1406 y primeros meses de 1407. Uno de ellos anota el pago hecho al «procurador de las albixaras, que abía naçido fillo al senyor rey de Siçilia» $\left(n .^{\circ} 23\right)$. Se refiere al nacimiento en Sicilia de Martín, hijo de Martín [II] el Joven, rey de Sicilia (fallecido en 1409) y primogénito del rey Martín el Humano (1395-1410), ocurrido en la Navidad de 1406 de su segundo matrimonio con Blanca Evreux de Navarra, luego reina de Navarra y mujer de Juan II $^{6}$. El acontecimiento precede en unos días a la muerte de la reina María de Luna, lugarteniente del reino (citada en $n^{\circ} 18$ y 30 ), primera esposa de Martín el Humano, y es comunicado en febrero siguiente a algunas ciudades peninsulares ${ }^{7}$. Otras entradas se refieren explícitamente a pagos realizados de deudas fiscales, de censales y de salarios del «anyo sexto» (n. ${ }^{\circ} 10,11,15,19$ y 20).

La procedencia aragonesa aparece confirmada por rasgos lingüísticos que encontramos en el texto y por el contenido de diversas entradas que hacen referencia a Zaragoza, ciudad a donde se dirigen enviados y procuradores de la aljama a tratar asuntos variados (n. ${ }^{\circ}$ $6,13,14,28,30$ y 31$)$, y también a Tudela (n. $\left.{ }^{\circ} 36\right)$. Es evidente que por el tipo de gastos realizados se debía de referir a una comunidad judía importante, relacionada con judíos de las dos localidades mencionadas. Una comparación de la onomástica de varios judíos y cristianos mencionados en las entradas y su identificación en docu-

6 Según el manual de novells ardits, vol. I, f. 148: «Dimarts VIII- Dia de carnestoltes. Aquest dia vench nova certa als honorables consellers que la senyora reyna de Sicilia, muller del senyor rey fill del senyor rey nostre En Marti et primogenit d'Aragó havia haut I fill»; $c f r$. D. GIRONA LLAGOSTERA, «Itinerari del rey En Marti», Anuari del Institut d'Estudis Catalans 5 (1913-14) págs. 515-654: pág. 607, n. ${ }^{\circ} 7$.

7 [Valencia] «Lo rey.- Per tal com sabem quen haurets plaer vos certificam que huy divenrdes XI dies del present mes [febrero], a IIII hores apres mija nit, havem reebut I correu for cuytat de la ciutat de Barchinona per lo qual nos han certificat ab lur letra com alli havia arrivada una nau de Sicilia ab alguns servidors de nostre molt car primogenit, lo rey de Sicilia, quins portaven letres e compta vende tot cert com nostra molt cara filla la reyna de Sicilia, la nit de Nadal ha parit per gracia de nostre senyor Deu, I bell fill, lo qual ha nom Marti», en ibid. (9), reg. 2249, f. $180 \mathrm{v}$. 
mentación ya publicada, apunta claramente a Tarazona ${ }^{8}$. Ello queda ratificado por una referencia explícita al çinto, un recinto fortificado de la ciudad (n. $\left.{ }^{\circ} 42\right)$.

Más allá del interés local, las 42 entradas conservadas del registro contable de gastos, el único hasta la fecha conocido para una comunidad hispanojudía bajomedieval -junto con otro catalán de reciente identificación ${ }^{9}-$, nos informan del funcionamiento de determinados aspectos de la vida religiosa, judicial, fiscal y económica de una comunidad judía situada en la confluencia de tres reinos en un periodo de conflictos, aparte de proporcionar interesantes aportaciones léxicas. El registro contable de gastos tendría un carácter oficial, y su finalidad sería la del control de los gastos realizados por la aljama, señalando primero la cantidad a pagar, seguida de una descripción de cargos muy variados, en relación a pagos por conceptos diversos.

En primer lugar, los gastos de protección de la aljama (que incluyen las cargas fiscales). El texto menciona diversas imposiciones fiscales reales: «fogaje» (n. $\left.{ }^{\circ} 4\right)$, «cena real» y «gobernación» $\left(n .^{\circ}\right.$ 18), «protección real» (n. ${ }^{\circ} 27$ ); o concejiles, como el censo que la aljama había vendido en agosto de 1391 al concejo de Tarazona por 3.000 sueldos, en un acto sospechoso que disimula una compra obligada de protección en momentos muy delicados y que se convierte

\footnotetext{
${ }^{8}$ Judería conocida para el periodo bajomedieval a partir de los valiosos estudios de José M. ${ }^{a}$ Sanz Artibucilla, publicados entre los años 1944-47 y 1949 en la revista Sefarad. Partiendo de estos estudios pioneros, y recogiendo los regestos de una abundante documentación notarial, vid M. A. Motis DOLADER, Los judíos de Tarazona en el siglo XIV. II, donde se mencionan algunos de los personajes citados en nuestro texto. Con anterioridad, este autor había estudiado la judería en M. A. Motis Dolader y M. ${ }^{\mathrm{a}}$ T. AinagA, «Patrimonio urbanístico aljamial de la judería de Tarazona (Zaragoza): La sinagoga, las necrópolis y las carnicerías», Revista de Historia Jerónimo Zurita 56 (1987) págs. 81-129.

9 Se trata del cuaderno de contabilidad por partida doble de Juçef Zabarra, recaudador, que contiene los asientos (por separado) de ingresos y gastos de la comunidad judía de Gerona (1443), que fue identificado por E. Feliu. Dichas cuentas, fiscalizadas por los recaudadores de cuentas (¿censores?) de la aljama, se localizan en el Arxiu Històric de Girona, Notarial Gi 2, 212, y fueron recientemente mostradas en la exposición El secret dels llibres: Els documents amagats dels jueus de Girona.
} 
en una tributación anual. Una protección pagada también en circunstancias periódicas, como las guardas del Viernes Santo, para la protección de la judería de la «Santa Pedrea» de las autoridades (n. ${ }^{\circ}$ 8). La conservación de los recintos protectores de la judería preocupa también a los oficiales de la aljama, y por ello se registran gastos por la reparación de los cimientos del muro $\left(n .^{\circ} 1\right)$, o el «adobo de las quiçaleras» de las puertas de la judería (n. $\left.{ }^{\circ} 12\right)$. A esos gastos hay que añadir los obsequios realizados a diferentes autoridades, como los regalos navideños enviados a «fraires» y a la justicia, jurados y prohombres de la ciudad (n. ${ }^{\circ} 32$ ); o el presente entregado a un canónigo de la catedral (n. $\left.{ }^{\circ} 22\right)$.

El endeudamiento de la aljama se incrementa con los pagos debidos de censos y censales contraídos con individuos, todos cristianos $\left(\mathrm{n}^{\circ} 3,19\right.$ y $\left.38 ; 39,40\right)$, o de préstamos debidos a otros judíos (n. ${ }^{\circ}$ 13, 20). Añádase a ello los salarios y pagos debidos a oficiales reales -baile y lugarteniente, y fiscal real- $\left(\mathrm{n}^{\circ}{ }^{\circ} 9,10,21\right.$ y 41), y gastos extraordinarios, como el pago realizado a los jurados por la pignoración de varios judíos que habían sido prendidos al desarrollar abiertamente su actividad laboral (vendimia) en día festivo (para los cristianos, claro) ( $\mathrm{n}^{\circ}{ }^{\mathrm{1}}$ ), o los ocasionados por la «linpia de la laguna» (n. ${ }^{\circ}$ 17). Extraordinario es también el cobro de 200 sueldos que la aljama debe pagar a los jurados por la «quema del çinto», es decir, el recinto amurallado, que sufriría frecuentes daños como consecuencia de las muchas hostilidades contra esta ciudad, fronteriza con Castilla y Navarra ( $\left.\mathrm{n} .^{\circ} 42\right)$. Aunque en mucha menor cuantía, la contabilidad recoge con frecuencia una serie de pagos realizados a notarios por la expedición de documentos diversos: cartas de censo, albalaes, copia de empara, ápocas (n. ${ }^{\circ} 3-5,14,18$, $27,37$ y 39$)$.

Más interesantes son las informaciones relativas a asuntos internos de la aljama, concretamente las referencias a la existencia de tres sisas -«carneçería, braçeaje, e logro e mercadería» (n. ${ }^{\circ}$ 9)-, que gravan, a favor «de la bolsa de la aljama», el consumo alimenticio (carnicería), ingresos por trabajo y rentas (brazaje), y el tráfico financiero y mercantil. Una serie de entradas está en relación con los pagos realizados a los oficiales de la aljama: Sueldos de clava- 
rios ( $\left.\mathrm{n}^{\circ} 11\right)$, que son los oficiales económicos de la aljama; contribuciones realizadas de los fondos comunes de la aljama a los «almosneros», por orden de los miembros del «consello» de la aljama (n. ${ }^{\circ}$ 25), y sobre todo, los pagos realizados al procurador de la aljama, cuyo papel es muy importante. Él es el que se desplaza a la corte para resolver arduos «aferes» de la reina, lo que le impide permanecer más tiempo en Zaragoza para ocuparse de un procedimiento judicial abierto contra un malsín (n. ${ }^{\circ} 30$ ), en el que va a jugar un papel destacado a juzgar por el pago que recibe de la aljama (n. $\left.{ }^{\circ} 34\right)$. Además, tenía que empezar consiguiendo de la reina un «previlejo de malsín» $\left(\mathrm{n}^{\circ} 33\right)$.

Un mismo asunto que acabo de mencionar y que aparece registrado en seis entradas, suponiendo a la aljama el gasto más elevado, se refiere al enjuiciamiento y ejecución de un malsín (cuya identidad no he logrado averiguar, ni tampoco los motivos de su acusación), y que tendría lugar a lo largo de $1406{ }^{10}$. Desde los 35 florines dados en pago a dos cristianos para que cesaran en su empeño de «defensar» a ese malsín (n. ${ }^{\circ}$ ); los 118 sueldos de gasto que suma lo pagado al judío encargado de llevarlo a Zaragoza, con la cantidad entregada a los «reçebtores de los testimonios», gasto sufragado en buena medida con los 11 florines que la aljama cobra de la viuda del malsín (n. $\left.{ }^{\circ} 28\right)$. Otras sumas complementarias incluyen el pago de 45 florines al merino de Zaragoza, que dio la sentencia, y a su lugarteniente (n. $\left.{ }^{\circ} 30\right)$; los 115 florines que costó reunir a los «rabís» de Zaragoza, y a otros de fuera que estuvieran en la ciudad, para obtener de ellos un «consello», es decir, una decisión halájica para saber si merecía tal castigo (n..$^{\circ} 31$ ); los 1.500 sueldos utilizados para ganar de la reina el «previlejo de malsín», o los mil sueldos

10 Una introducción al problema de la malsindad, que recoge bibliografía sobre el tema, en A. BLASCO MARTíneZ, «Los malsines del reino de Aragón: Una aproximación», en Proceedings of the Eleventh World Congress of Jewish Studies. Division B. 1 (Jerusalem 1994) págs. 83-90. El tema del malsin aparece recogido en un poema de Šelomó de Piera coetáneo de este registro. $C f r$. J. TARGARONA BORRÁS y Á. SÁEnZ-BAdillos, «Poemas y epigramas de Šelomoh ben Mešulllam de Piera (edición crítica y traducción)», en Judaísmo Hispano, Estudios en memoria de José L. Lacave Riaño, ed. E. Romero (Madrid 2002), volumen I, págs. 179-208; pág. 197. 
pagados al procurador de la aljama por la muerte (n. $\left.{ }^{\circ} 34\right)$. El elevado coste y la complejidad de los procedimientos puestos en práctica permiten deducir la peligrosidad que ante las autoridades de la aljama representaba dicho malsín.

De sumo interés son los diversos cargos relativos a inmuebles e instituciones dedicados a fines benéficos de la aljama, como el «espital del almosna» (entiéndase «almosna» en el sentido de beneficencia de la aljama), cuyo censo se paga, igual que las reparaciones llevadas a cabo por Don Ezmel Azamel (n. 3 y 15), del mismo modo que el censo de las «casas del almosna de Šelomó del Mirón» (n. $\left.{ }^{\circ} 15\right)$. También recibe dinero para reparación «la sinoga», junto con la «casa del almosna» (n. ${ }^{\circ} 26$ ). Se registran pagos de dinero para encargados sinagogales, «los que sierven la tribuna» de la sinagoga, y los que «fazen oraçión», entre otros, el salíah sibbur y el hazzán $\left(\mathrm{n}^{\circ} 24\right)$. Además de éstos, otro pago que aparece consignado a la aljama es el relativo a la compra de las «cuatro especies» de plantas usadas durante la celebración de la Pascua de «Cabanillas» o Sucot, a saber, etrog (ponzil) o cidra, lulav (palma), [tres ramas de] hadas (murta) o mirto y [dos ramas de] 'arabá (gatido) o sauce, cuyo gasto es compartido a «escote» (n. $\left.{ }^{\circ} 29\right)$. Obsérvese que siempre se prefiere el término romance al hebreo. Antes mencionaba el recurso a una decisión halájica de Zaragoza en relación al malsín, pero otro cargo refiere también la demanda de «consello» (cuyo asunto desconocemos) por otro judío de Tarazona, Yishac Alcalhorrí, cuyos gastos de viaje y estancia de seis días corren a cargo de la aljama, indicio posible de que actuara en su nombre ( . $\left.^{\circ} 14\right)$.

Poco antes, este mismo judío había acudido a Zaragoza con un asno para llevar un presente de manzanas a don Benvenist (n. ${ }^{\circ}$ 6). Y es que aparecen registrados ciertos cargos que reflejan las relaciones de la aljama con determinados financieros judíos de Zaragoza y de Tudela, cuyo auxilio puede ser útil en momentos de apuro. La aljama envía a Yuçaf ben Usillo a Zaragoza, a donde va con su hijo y dos asnos, a resolver ciertas deudas, entre ellas, la debida a doña Tolosana y a don Yehudá ben Labí, pertenecientes ambos a la aris- 
tocrática familia de los Caballería ${ }^{11}$ (n. $\left.{ }^{0} 13\right)$. Por último, se registra un pago por la aljama, a través de su procurador, a Šemuel ben Ban Nist (n. ${ }^{\circ} 36$ ), judío vecino de Tudela, el mismo relacionado con los Benvenist castellanos y con el soriano Simuel Pesquer, y que en 1399 recibe un guiaje para asistir en Zaragoza a la boda de un sobrino de Bonafós de la Caballería ${ }^{12}$. En 1407-8 se registra su actividac en el mercado crediticio de Tudela ${ }^{13}$.

Sólo unas palabras acerca de la lengua empleada, en especial del léxico. La utilización del romance es generalizada en todo el texto, de tal forma que sólo nos encontramos con dos hebraísmos -«malsín», «cahal» (n. $\left.{ }^{\circ} 38\right)$-, así como una abreviatura de la bendición del monarca $\left(n .^{\circ} 21,22\right.$ y 27$)$. De manera sorprendente, el registrador ni siquiera hace uso de términos acuñados en hebreo en relación a instituciones de la aljama (menciona a «consello» de la aljama - n. $^{\circ}$ $25-$, y «clavarios» $-n .^{\circ} 11$ y 25 ), o relativos a su vida religiosa ( $\ll$ los que sierven la tribuna», «los que fazen la oraçión»). Es también el caso del empleo de vocablos romances («palmas», «ponziles», «murta» y «gatidos») para designar las «cuatro especies» de plantas utilizadas en Sucot (fiesta designada con el vocablo «Cabanillas»). Por el contrario, nos encontramos con tecnicismos y cultismos latinizantes lo que denota cierta familiaridad con los usos generalizados en ese momento entre los juristas cristianos, así como su preferencia frente a los términos hebreos. Es el caso de la repetida

1 Tolosana tenía un hermano de nombre Yehudá. Es posible que el don Benvenist citado en $\mathrm{n}^{\circ} 6$ pueda ser identificado con el homónimo marido de doña Tolosana, fallecido en 1411. Un aspecto de la interesante personalidad de esta mujer a través de su testamento de 1418 , en A. BlasCo MARTínEZ, «Mujeres judías zaragozanas ante la muerte», Aragón en la Edad Media 9 (1991) págs. 77-120: págs. 88-93.

12 Cfr. M. Diago Hernando, «La movilidad de los judíos a ambos lados de la frontera entre las Coronas de Castilla y Aragón durante el siglo XIV», Sefarad 63 (2003) págs. 237-282: págs. 246-247.

13 Cfr. J. CARrasco Pérez, «Cambistas y 'banqueros' en el reino de Navarra (siglos XIII-XV). Dinero, banca y crédito en la Navarra bajomedieval», en Banchi pubblici, Banchi privati e monti di pietà nell'Europa preindustriale. Amministrazione, tecniche operative e ruoli economici (Genova 1991) págs. 943-962: pág. 961. 


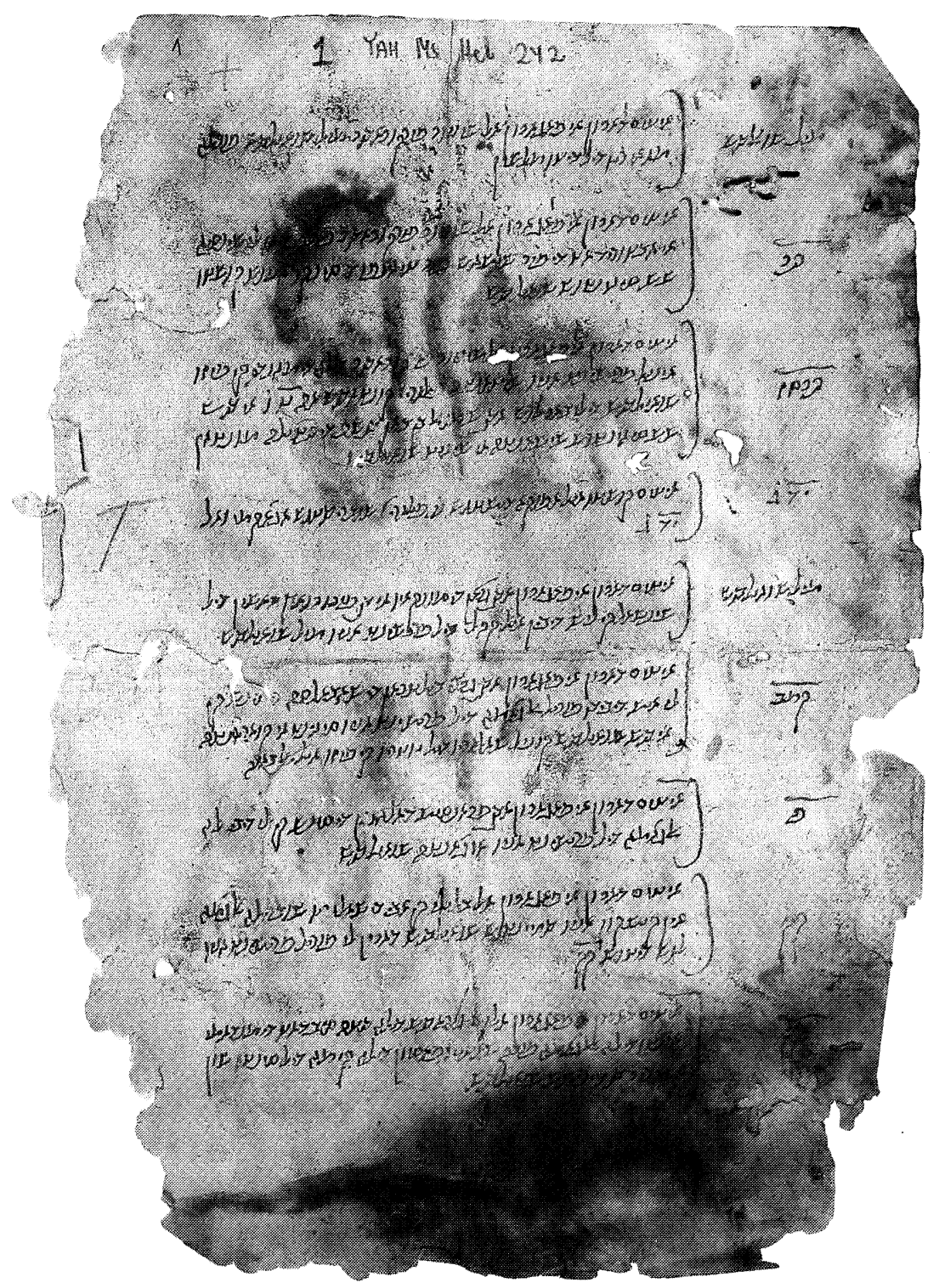

Fig. 1. JNUL Yah. Ms. Heb. 242, f. 3b,

reprod. en R. WEISER (ed.), Books from Spain, p. 151. 
partícula «item», y sobre todo del empleo circunstancial de «juxta» (de acuerdo con) -en relación con «ley judaica» (n. $\left.{ }^{\circ} 31\right)$-, alternando su uso con el de la preposición «segum» en otros casos. O el uso del sustantivo «consello» (n. ${ }^{\circ} 14$ y 31 ), que designa una decisión jurídica (consilium), en este caso de contenido halájico. Los topónimos utilizados conservan las sordas intervocálicas («Tutela»), aunque se muestra a veces cierta vacilación en su uso: Çaracoçta (n. ${ }^{\circ} 6$ y 13) frente a «Çaragoça» $\left(n .^{\circ} 14,28\right.$ y 30$)$.

\section{DOCUMENTACIÓN}

Presento a continuación una lectura del texto romance en escritura hebrea, seguido de su transcripción, para la que he utilizado la norma seguida por José L. Lacave en su «Pleito judío por una herencia en aragonés y caracteres hebreos (notas acerca del procedimiento judicial en los tribunales judíos aragoneses)» ${ }^{14}$, y teniendo también en cuenta, en la medida de lo posible, el uso de la época reflejado en los documentos romances. He añadido entre corchetes letras o palabras reconstruidas como consecuencia de la mala conservación del documento, roto y con manchas de humedad. Como es usual en los textos medievales, éste no tiene puntuación. Por ello, la que aparece ha sido añadida. En los casos en que lo que va entre corchetes está en cursiva, se trata de añadidos que no aparecen en el texto. Y lo añadido entre corchetes en cursiva y negrita corresponde a la fórmula de bendición del monarca traducidos del hebreo.

[N1]

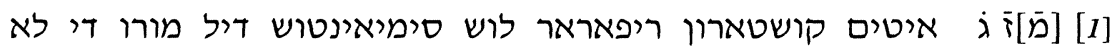
ג'ודיריאה קואראנטה אי שיאיט שואילדוש אי טריש סיש דינירוש.

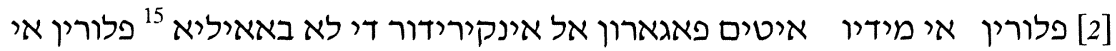
מידיו פוריל פרישין אניו.

14 Sefarad 31 (1971) pág. 49.

15 Lectura sugerida. 


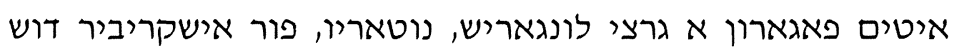

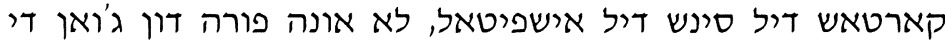

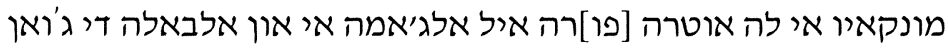

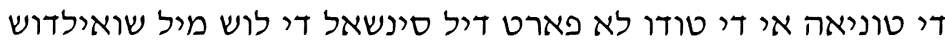

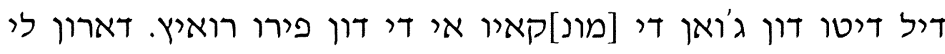

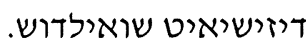

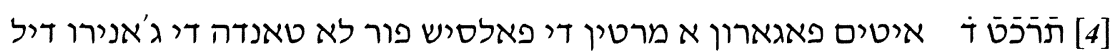

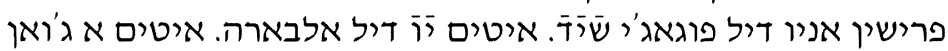

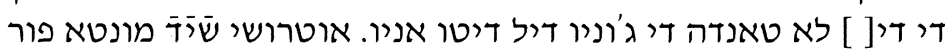
טודו ${ }^{16}$ שישסיאינטוש בינט אי ניואי דואיב שואילדוש אי קואטרו דינירוש.

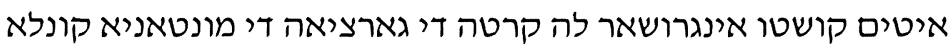
נוטא טריזי שואילדוש.

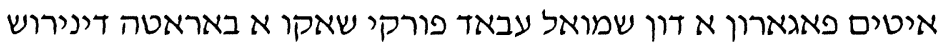

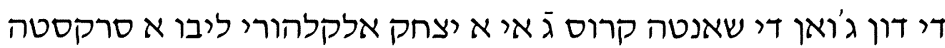

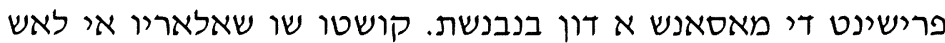

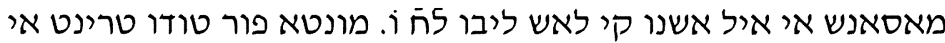
אוג'ו שואילדוש אי שיש דינירוש.

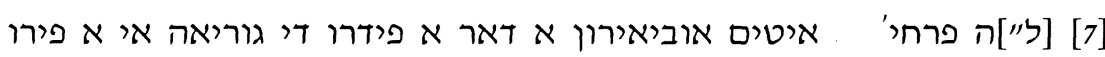

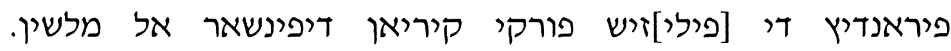
אוביאירונליש א דאר טרינטה סינקו פלורי'.

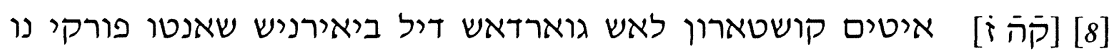

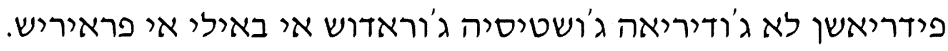

מונטו פור טודו סיאינט אי סינקו שואילה ג'ורדוש אי שיאיט דינינירירוש.

$$
\text { מיל קָק מונר }
$$

איטים פאגארון אדון פירו קאבי[רו לוקט]יניאינט די באילי פור ראזון

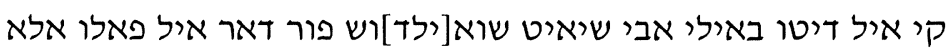

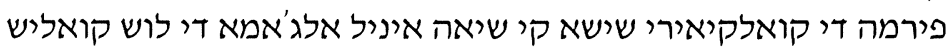

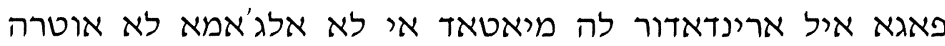

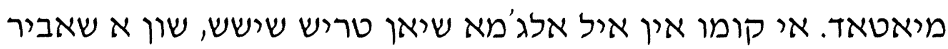

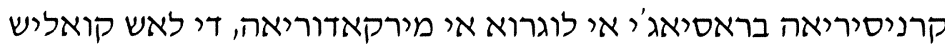

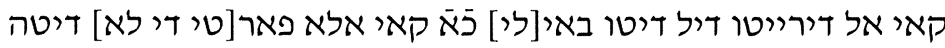

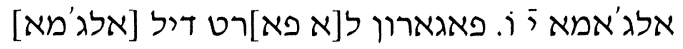

16 A continuación aparece la palabra טריזיינ que va tachada. 
איטים פאגארון אל דיטו דון פירו קאב[י]רו קי [לי] איראן דיבידוש $\bar{p}[10]$

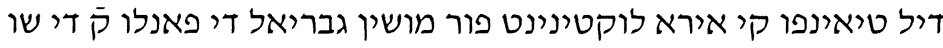

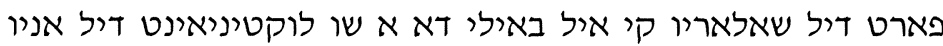

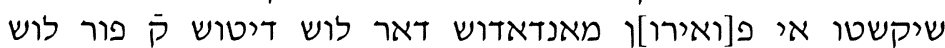

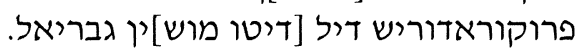

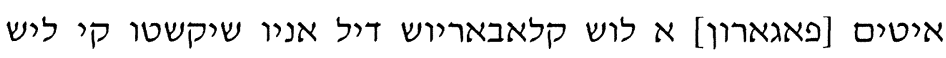
דיביאן לא [אלג'] אמה שיגום שי שי טרואיבה פור שוש קונטוש בינט אי לי שי לי

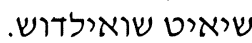

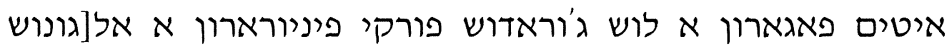

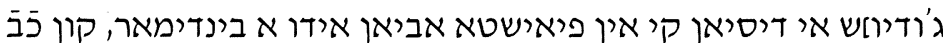
קי דיאירון א יצחק [מ]סעוד פודי פור אדובאר לאש קיסאליראש אירא די לאש

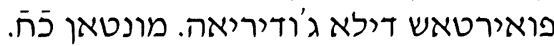

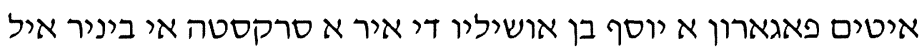

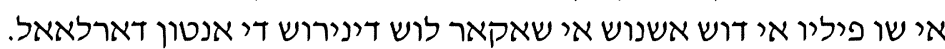

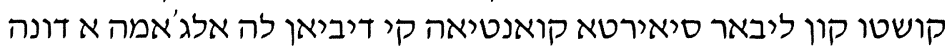

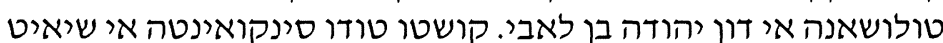
שואילד] [וש] אי אוג'ו דינירוש.

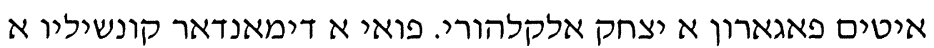

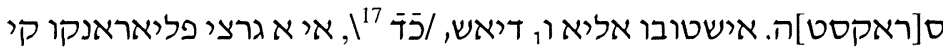

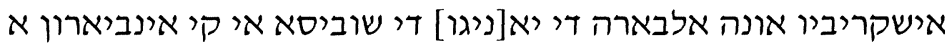

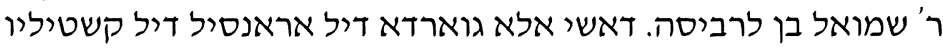

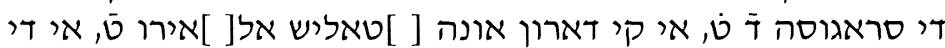

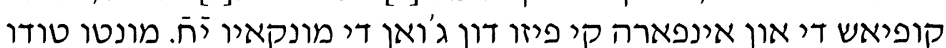

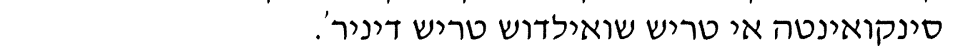

$i[5][11]$

$\bar{n} \overline{5}[12]$

in

$\dot{\lambda} \bar{\lambda} \bar{\jmath}[14]$

$$
\text { [רעז }
$$

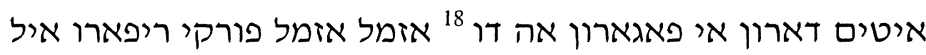

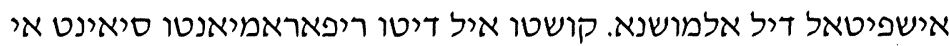

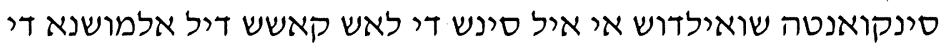

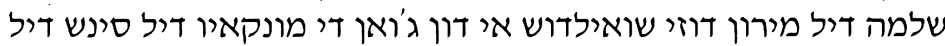

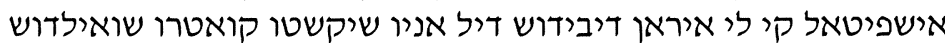
אי דיל אניו פרישינט אוג'ו שואילדוש. מונטא טודו קיערד.

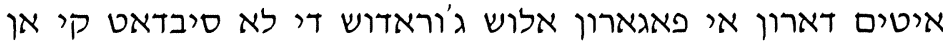

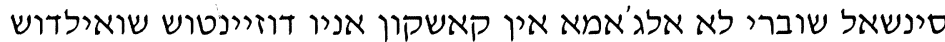

17 Cifra insertada entrelíneas.

18 Sic. 
דישדיל אניו די לא פישיקוסיון די לוש ג'ודיאוש [ ] אקא. דארון ליש

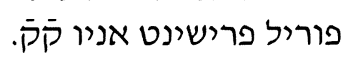
איטים דארון אי פאגארון פורה לא ל[ינ]פיאה די לא לאגונה דיאיז

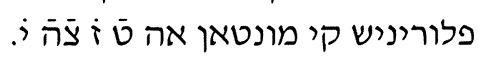

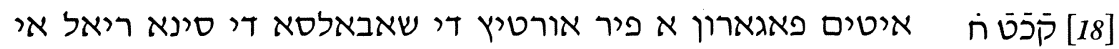

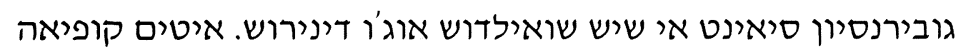

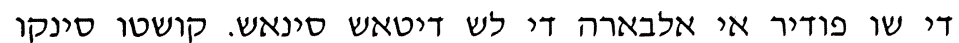

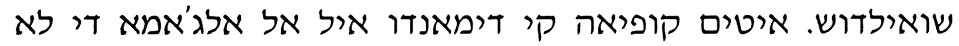

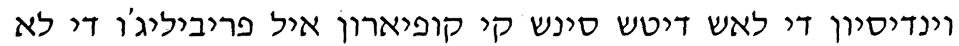

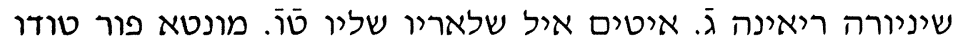

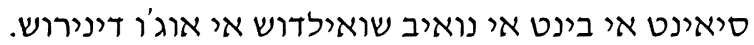

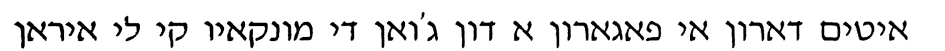

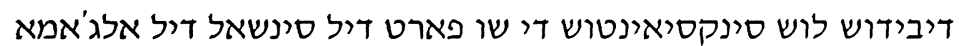

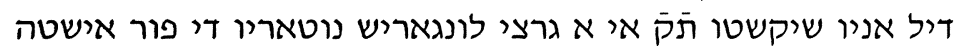

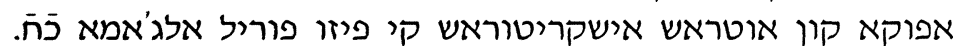

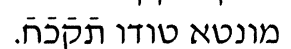

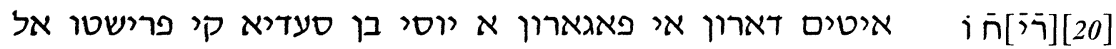

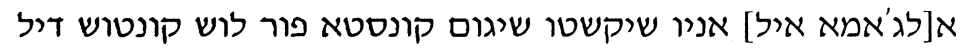

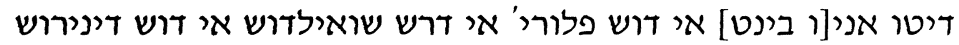

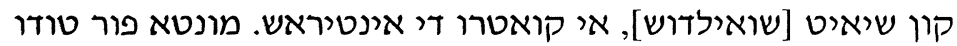
דוזיינטוש דיזיאוג'ו שואילדוש אי שיש דינואי דינירוש.

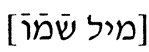

\footnotetext{
איטים דארון א מיגאל די לא פיירא פישקאל דיל שיניור ריאי י"א ${ }^{19}$

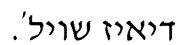

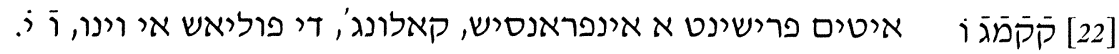

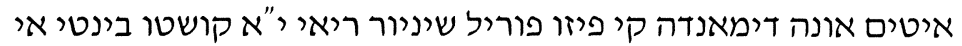

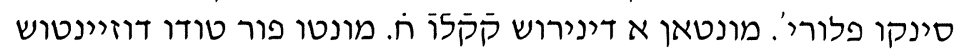

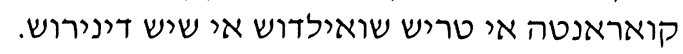

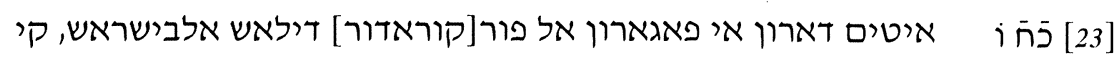
אביאה נאסידו פיליו אל שיניור ריאי די שיסיוריא פיא טריש פיוריש פלורי'. [24] ק̄מן טריבונא. [פ]אגארון סיאינט אי קואראנטה שואילדוש.

19 יברכהו אלהים.
} 


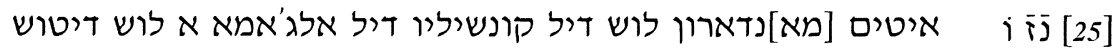

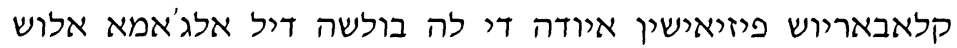
אלמושנירוש סינקואנטה אי שיאיט אי מידיו.

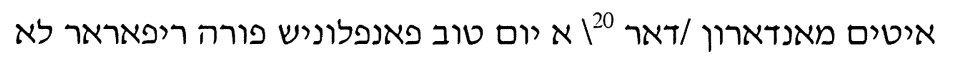

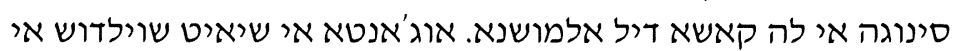

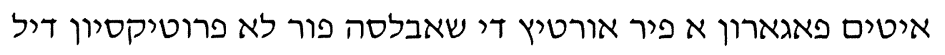

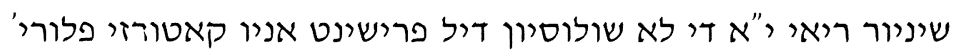

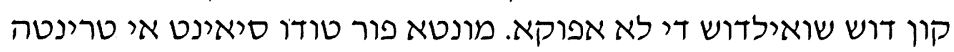
סינקו שואילדוש.

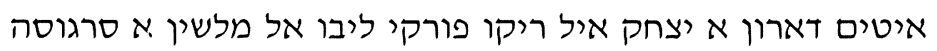

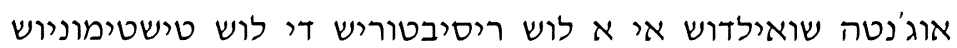

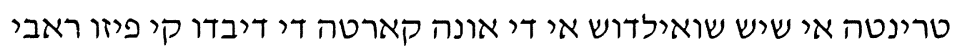

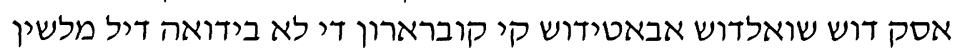

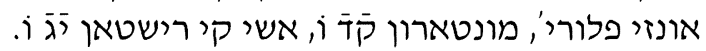

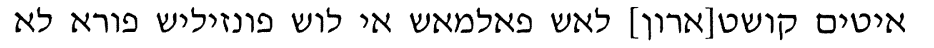

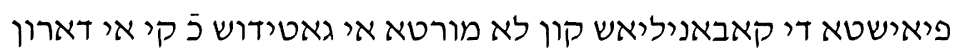

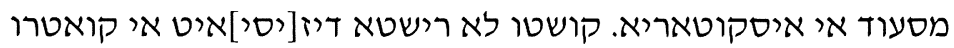

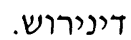

\section{[iं]}

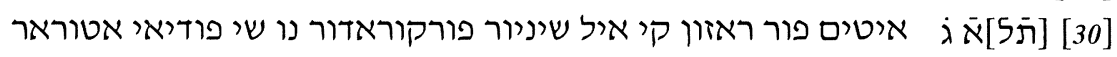

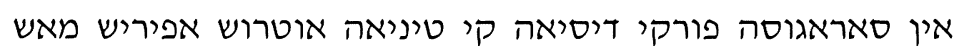

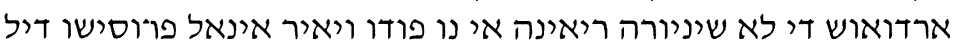

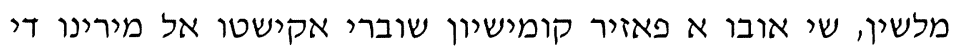

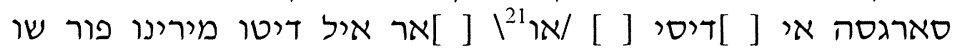

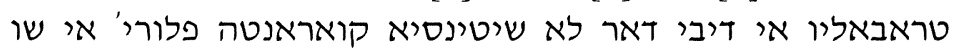

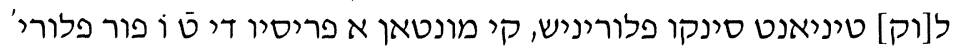

$$
. \dot{\lambda} \bar{\kappa} \bar{\jmath}
$$

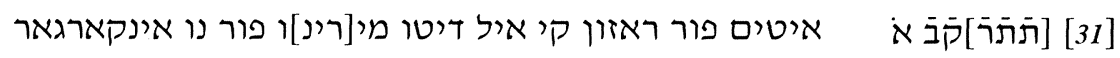

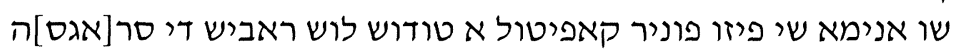

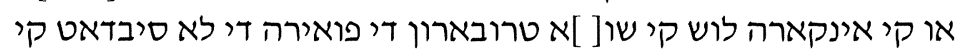

20 Esta palabra está insertada entrelíneas.

${ }^{21}$ Palabra insertada entrelíneas. 


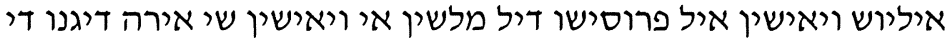

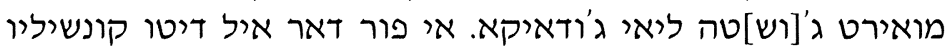

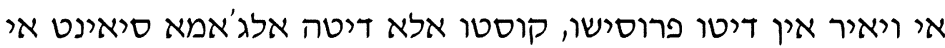

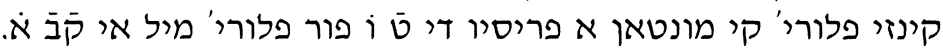

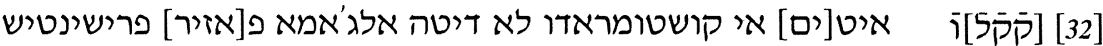

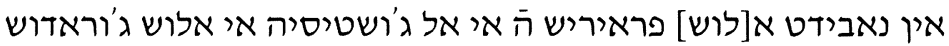

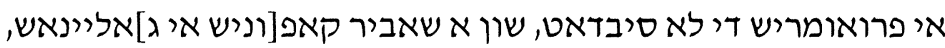

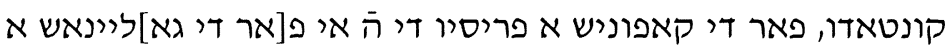

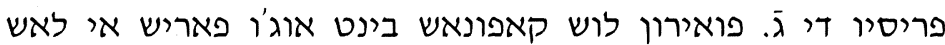

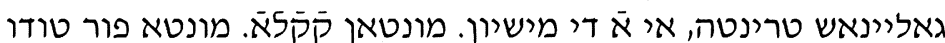

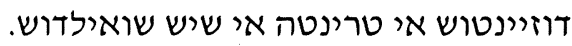

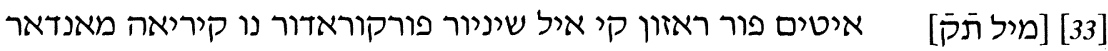

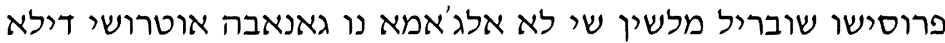

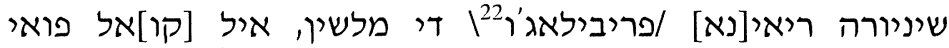

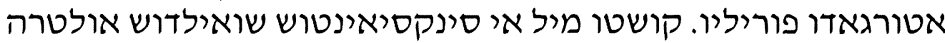

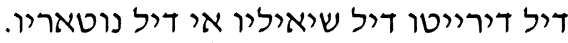
שומה

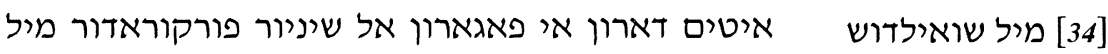
שואילדוש פורה מואירט דיל דיטו מלשין.

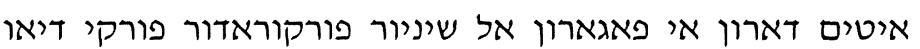
$\bar{\gamma} \bar{\gamma}[35]$ לישינסיא אי אבטורידאט די פירוך פירוך שישאש פור טיאינינפור פורי די סינקו אניוש. קושטו ששסיאינטוש שואילדוש.

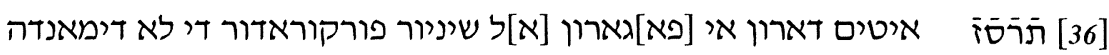

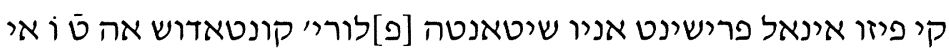

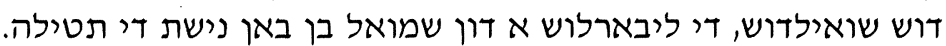
מונטאן ששסיאינטוש שישאנטה אי שיאיט שואיואילדי[י] שיא. [37] ואל זٓ⿱ ג.

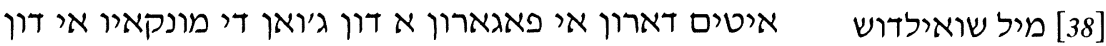

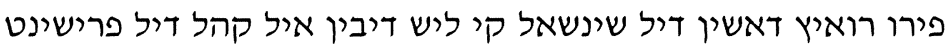

אניו מיל שואילדוש.

22 Palabra insertada entrelíneas. En la línea de escritura aparece tachada la palabra פרוסישו. 
איטים דארון אי פאגארון א דון גרצי בילטראן די שאבאלסה [די

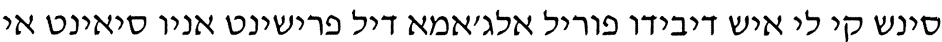

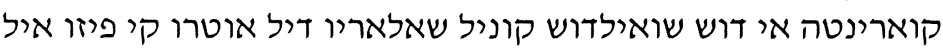

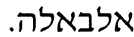

איטים דארון אי פאגארון א דון פראנסיש דאלאג[ו]ן די סינש קי לי

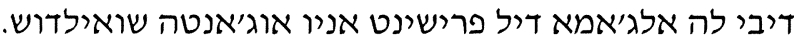

איטים דארון אי פאגארון אל באילי קי אבי די שאלאריו שוברי לה

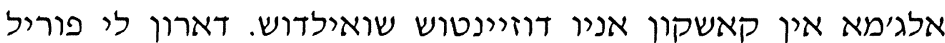
פרישנט אניו לוש דיטוש קשוש קניק.

איטים דארון אי פאגארון א לוש ג׳וראדוש די לא דיטה סיבדאט די

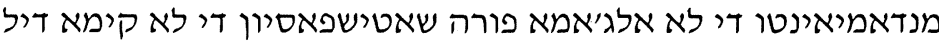
סינטו, שון א שאביר דוזיינטוש די אלגיאמאי פואילדוש.

ג

\section{TRANSCRIPCIÓN}

[1a]

[1] [4]7 s[ueldos], $3 \mathrm{~d}$ [ineros] Item, costaron reparar los çimientos del muro de la judería cuarenta e siet sueldos e tres dineros.

[2] Florín e medio Item, pagaron al enquiridor de la baylía florín e medio por el presén anyo.

[3] [17 s.] Item, pagaron a Garci Longares, notario, por escribir dos cartas del çens del espital, la una pora don Johan de Moncayo e la otra [po]ra el aljama e un albalá de Johan de Tonya e de todo la part del çensal de los mil sueldos del dito don Johan de [Mon]cayo e de don Pero Ruiz. Dáronle dizisiet sueldos.

[4] 629 s. 4 d. Item, pagaron a Martín de Falçes por la tanda de janero ${ }^{23}$ del presén anyo del fogaje 314 s. Item, 16 s. del albará. Item, a Johan de De[ ] la tanda de junio del dito anyo. Otrosy 314 s. Monta por todo sesçientos vent e nuev sueldos e cuatro dineros.

23 Se refiere al primer plazo semestral de pago. 
[5] 13 s. Item, costó engrosar la carta de García de Montanya conla nota, treze sueldos.

[6] $38 \mathrm{s.} 6$ d. Item, pagaron a don Šemuel 'Abad porque sacó a barata ${ }^{24}$ dineros de don Johan de Santa Cruç 3 s. A Yishac Alcalhorrí levó a Çaracoçta present de maçanas a don Benvenist. Costó su salario e las maçanas e el asno que las levó 35 s. 6 d. Monta por todo trent e ocho sueldos e ses dineros.

[7] [3]5 flori. Item, enviaron a dar a Pedro de Gurrea e a Pero Ferrández de [Feli]zes porque querían defensar al malsín. Oviéronles a dar trenta çinco flori.

[8] [105 s. 7 d.] Item, costaron las guardas del Viernes Santo porque no pedreasen la judería justiçia, jurados e bayle e fraires. Montó por todo çient e çinco sueldos e siet dineros.

[Suma] mil 200 s. $^{25}$

$[1 b]$

[9] [10 s.] 6 d. Item, pagaron a don Pero Cave[ro loct]enient de bayle por razón que el dito bayle abe siet sue[ld]os por dar el palo a la firma ${ }^{26}$ de cualquiere sisa que sea enel aljama de los cuales paga el arrendador la miatad e la aljama la otra miatad. E como en el aljama sean tres sisas, son a saber carneçería, braçeaje e logro e mercadería de las cuales cae el dereyto del dito bai[le] $21 \mathrm{~s}$. cae a la par[te de la] dita aljama 10 s. 6 d. Pagaron l[a par]t del [aljama].

[10] $100 \mathrm{~s}$. Item, pagaron al dito don Pero Cav[e]ro que [le] eran debidos del tienpo que era loctenient por Mosén Gabriel de Fanlo 100 s. de su part del salario que el bayle da a su loctenient del anyo sexto e f[uero]n mandados dar los ditos 100 s. por los procuradores del [dito Mos]én Gabriel.

[11] [2]7 s. Item, [pagaron] a los clavarios del anyo sexto que les debían la [alj]ama segum se trueva por sus contos vent e siet sueldos.

\footnotetext{
${ }^{24}$ Venta o subasta a precio rebajado.

25 La suma exacta es 1197 sueldos y 5 dineros.

26 Quizás, en el sentido de rubricar.
} 
[12] $28 \mathrm{~s}$. Item, pagaron a los jurados porque pinyoraron a al[gunos judio]s [qu]e decían que en fiesta avían ido a vendimar, con $22 \mathrm{~s}$. que dieron a Yishac [M]es'od por adobar las quiçaleras de las puertas de la judería. Montan $28 \mathrm{~s}$.

[13] 57 s. 8 d. Item, pagaron a Yuçaf ben Usillo ${ }^{27}$ de ir a Çaracoçta e venir él e su fillo e dos asnos e sacar los dineros de Antón Darlael. Costó con levar çierta cuantía que devían la aljama a dona Tolosana e don Yehudá ben Labí. Costó todo cincuenta e siet sueld[os] e ocho dineros.

[14] 53 s. 3 d. Item, pagaron a Yishac Alcalhorrí. Fue a demandar consello a Ç[aracoçt]a. Estuvo allá 6 días, 124 s./ e a Garci Pallaranco que escribió una albará de Yé[nigo] de Soviça e que enviaron a R. Šemuel ben La Rebiça. Dase a la guarda del arancel del castillo de Çaragoça 4 s. 9 d., e que daron una [ ]tales al[ ]ero 9 s., e de copias de un enpara ${ }^{28}$ que fizo don Johan de Moncayo $18 \mathrm{~s}$. Montó todo cincuenta e tres sueldos tres diner.

\section{[Suma 276 s. 5 d.]}

$[2 a]$

[15] 174 s. Item, daron e pagaron a Do ${ }^{29}$ Ezmel Azamel porque reparó el espital del almosna. Costó el dito reparamento çient e çincuenta sueldos e el çens de las casas del almosna ${ }^{30} \mathrm{de}$ Šelomó del Mirón doce sueldos e don Johan de Moncayo del çens del espital que le eran debidos del anyo sexto cuatro sueldos e del anyo present ${ }^{31}$ ocho sueldos. Monta todo $174 \mathrm{~s}$.

[16] $200 \mathrm{~s}$. Item, daron e pagaron a los jurados de la çibdat que an çensal sobre la aljama en casc'un anyo dozientos sueldos desd'el anyo de la pesecuçión de los judíos [ ] acá. Dáronles porel present anyo $200 \mathrm{~s}$.

27 También Benosiello.

28 Se refiere al documento que comunica una confiscación o secuestro de bienes.

29 Sic.

${ }^{30}$ La almosna es la beneficencia de la aljama.

31 Parece referirse a 1407. 
[17] 95 s. 10 d. Item, daron e pagaron pora la l[in]pia de la laguna diez florines que montan a 9 s. $7 \mathrm{~d}^{32}, 95 \mathrm{s.} 10 \mathrm{~d}$.

[18] 129 s. 8 d. Item, pagaron a Per Ortiz de Sabalça de çena real e gobernaçión çient e seis sueldos, ocho dineros. Item, copia de su poder e albará de las ditas çenas, costó çinco sueldos. Item, copia que demandó él al aljama de la vendiçión de las ditas çenas que copiaron el privilejo de la senyora reina ${ }^{33} 3 \mathrm{~s}$. Item, el salario salió $15 \mathrm{~s}$. Monta por todo çient e vent e nuev sueldos e ocho dineros.

[19] $528 \mathrm{~s}$. Item, daron e pagaron a don Johan de Moncayo que le eran debidos los çinç̧ientos de su part del çensal del aljama del anyo sexto 500 s. e a Garci Longares notario de por esta ápoca con otras escrituras que fizo porel aljama $28 \mathrm{~s}$. Monta todo $528 \mathrm{~s}$

[20] [21]8 s. 6 d. Item, daron e pagaron a Yuçé ben Sa adiá que prestó al a[ljama el] anyo sexto segum consta por los contos del dito any[o vent] e dos flori. e dos sueldos e dos dineros con siet [sueldos], e cuatro [dineros] de enterés. Monta por todo dozientos diziocho sueldos e ses dineros.

[Suma 1346 s.]

[2b]

[21] [10 s.] Item, daron a Miguel de la Feyra, fiscal del senyor rey, Dios le bendiga, diez sueldos.

[22] 243 s. 6 d. Item, present a En Françés, calonge, de pollas e vino, 6 s. $10 \mathrm{~d}$. Item una demanda que fizo porel senyor rey, Dios le bendiga, costó vente e çinco flori., montan a dineros 236 sueldos, 8 dineros. Montó por todo dozientos cuarenta e tres sueldos e seis dineros.

\footnotetext{
32 Se registra aquí una variación al alza en el precio del florín.

33 La referencia es, quizás, a María de Luna, primera esposa de Martín el Humano y lugarteniente del reino, fallecida en diciembre de 1406.
} 
[23] 28 s. 6 d. Item, daron e pagaron al por[curador] de las albixaras ${ }^{34}$, que abía naçido fillo al senyor rey de Siçilia, tres flori. ${ }^{35}$

[24] $140 \mathrm{~s}$. Item, a los que fazen oraçión a la sinoga e sierven la tribuna [p]agaron çient e cuarenta sueldos.

[25] 57 s. 6 d. Item, [ma]ndaron los del consello del aljama alos ditos clavarios fiziesen ayuda de la bolsa del aljama a los almosneros çincuenta e siet e medio.

[26] 87 s. 9 d. Item, mandaron $\backslash d a{ }^{36} /$ a Yon Tob Panplonés pora reparar la sinoga e la casa del almosna ochenta e siet sueldos e nuev diner.

[27] 135 s. Item, pagaron a Per Ortiz de Sabalça por la protecçión del senyor rey, Dios le bendiga, de la soluçión del present anyo catorze flori. con dos sueldos de la ápoca. Monta por todo çient e trenta çinco sueldos ${ }^{37}$.

[28] 13 s. 6 d. Item, daron a Yishac el rico porque levó el malsín a Çaragoça ochenta sueldos e a los reçebtores de los testimonios trenta e ses sueldos e de una carta de debdo que fizo rabí Açac dos sueldos abatidos ${ }^{38}$, que cobraron de la vidua del malsín onze flori., montaron 104 s. 6 d. ${ }^{39}$ asi que restan 13 s. 6 d.

[29] [17 s.] 4 d. Item, cost[aron] las palmas ${ }^{40}$ e los ponziles pora la fiesta de Cabanillas con la murta e gatidos ${ }^{41} 20$ s. que y ${ }^{42}$

34 Buenas noticias («albricias»).

35 En navidad de 1406. La noticia llega en febrero de 1407.

36 Esta palabra aparece insertada sobre la línea.

37 A nueve sueldos y seis dineros por florín.

38 «Abatir» es reducir la cantidad, valor o precio de las cosas, restar o descontar: De la suma inicial (118 sueldos) son «abatidos» o descontados once florines.

39 A nueve sueldos y seis dineros por florín.

40 Son las cuatro especies (arba'á minim) de plantas usadas durante la Pascua de Sucot: lulav (palma), etrog o cidra (ponzil), tres ramas de hadas o mirto (murta) y dos ramas de 'arabá o sauce (gatidos).

41 «Gatido». También «gatilo» o «gatino». Vid. DRAE, s.u. «sauzgatillo» (latín «cattus», catalán «gatell») (22a ed. Madrid 2001), y J. COROMINAS y J. A. PASCUAL, Diccionario crítico-etimológico castellano e hispánico, s.u. «sauce» (Madrid 1980).

42 Con valor de pronombre adverbial. 
daron Mes'od e escotaría ${ }^{43}$. Costó la resta diz[içi]et [sueldos] e cuatro dineros ${ }^{44}$.

[Suma] 732 s. [13 d.]

$[3 a]$

[30] [43]1 s. 3 d. Item, por razón que el senyor porcurador no se podíe aturar ${ }^{45}$ en Çaragoça porque deçía que tenía otros aferes más arduos de la senyora reina e no pudo veer enel proçeso del malsín, se ovo a fazer comisión sobre aquesto al merino de Çaragoça, e [ ]deçe [ ] lo/ [ ]ar el dito merino por su traballo e debe dar la setençia quaranta flori. e su $1[$ oc]tenient çinco florines, que montan a preçio de 9 s. 7 d. por flori., 431 s. $3 \mathrm{~d}$.

[31] [1]102 s. 1 d. Item, por razón que el dito me[rin]o por no encargar su ánima, se fizo poner capitol a todos los rabís de Çar[agoç]a o que encara los que so[ ] trovaron de fuera de la çibdat que ellos veesen el proçeso del malsín e veesen si era digno de muert j[ux]ta ${ }^{46}$ ley judaica. E por dar el dito consello e veer en dito proçeso costó a la dita aljama çient e quinze flori. que montan a preçio de $9 \mathrm{~s} .7 \mathrm{~d}$. por flori., mil e $102 \mathrm{~s} .1 \mathrm{~d}$.

[32] [23]6 s. It[em] e costumrado la dita aljama f[azer] presentes en Navidat a [los] fraires 5 s., e al justiçia e alos jurados e proomres de la çibdat, son a saber cap[ones e g]allinas, contado, par de capones a preçio de $5 \mathrm{~s}$. e p[ar de ga]llinas a preçio de 3 s. Fueron los capones vent ocho pares e las gallinas trenta, e 1 s. de misión ${ }^{47}$. Montan 231 s. Monta por todo dozientos e trenta e ses sueldos.

${ }^{43}$ «Escotar» es pagar cada uno la parte o cuota que le toca del gasto hecho en común por varias personas (DRAE).

${ }^{44}$ La Pascua de Cabañuelas o de Sucot de 5167 tuvo lugar a fines de septiembre de 1406.

45 Semánticamente, próximo al verbo homónimo catalán (permanecer durante más tiempo o detenerse) Cfr. F. BAER, Die Juden in Christhichen Spanien. I. Aragonien und Navarra (Berlin 1929) nº 463 \# 4 (pág. 731).

${ }^{46}$ Conforme a.

47 Es decir, 28 pares de capones y 30 de gallinas, más un sueldo de misión, y 5 s. a los «fraires». 
[33] [Mil 500 s.] Item, por razón que el senyor porcurador no quería mandar fer proçeso sobr'el malsín si la aljama no ganaba otrosí de la senyora rei[na] Iprevilejo/ de malsín, el [qu]al fue atorgado porello. Costó mil e çincçientos sueldos ultra del dereyto del seello e del notario ${ }^{48}$.

Suma tres mil 269 s. 4 d.

$[3 b]$

[34] Mil sueldos Item, daron e pagaron al senyor porcurador mil sueldos pora muert del dito malsín.

[35] $600 \mathrm{~s}$. Item, daron e pagaron al senyor porcurador porque dió lisençia e abtoridat de fer sisas por tienpo de çinco anyos. Costó sesçientos sueldos.

[36] $667 \mathrm{~s}$. Item, daron e [pa]garon [a]l senyor porcurador de la demanda que fizo enel present anyo setanta [f]lori. contados a 9 s. 6 d., e dos sueldos, de levarlos a Šemuel ben Ban Nist de Tutela. Montan sesçientos sesanta e siet sueld[o]s.

[37] 14 s. 3 d. Item, costó el ápoca destos 70 flori. sobreditos a Jacme Val 14 s. 3 d.

[38] Mil sueldos Item, daron e pagaron a don Johan de Moncayo e don Pero Ruiz d'Asín del çensal que les deben el cahal del present anyo mil sueldos.

[39] 142 s. Item, daron e pagaron a don Garci Beltrán de Sabalça [d]e çens que le es debido porel aljama del present anyo çient e cuarenta e dos sueldos conel salario del otro que fizo el albalá.

[40] 80 s. Item, daron e pagaron a don Françés d'Alagón de çens que le debe la aljama del present anyo ochenta sueldos.

[41] 200 s. Item, daron e pagaron al bayle que abe de salario sobre la aljama en casc'un anyo dozientos sueldos. Dáronle por el present anyo los ditos $200 \mathrm{~s}$.

[42] $200 \mathrm{~s}$. Item, daron e pagaron a los jurados de la dita çibdat de mandamiento de la aljama pora satisfaçión de la quema del çinto, son a saber dozientos sueldos.

[Suma] 3 mil 903 s. 3 d.

${ }^{48}$ Que no especifica su cuantía. 


\section{ÍNDICE DE NOMBRES PROPIOS}

Abad, v. Šemuel

Açac, Rabí, 28

Alagón, v. Françés

Alcalhorrí, v. Yishac

Antón Darlael, 13

Asín, v. Pero Ruíz

Azamel, v. Ezmel

Beltrán, v. Garci

Ben Labí, vid. Yehudá

Ben La Rabiça, v. Šemuel

Ben Sa ádiá, v. Yuçé

Ben Usillo, v. Yuçaf

Ben Ban Nist, v. Šemuel

Benvenist, Don (Zaragoza) 6

Çaracoçta. Çaragoça (Zaragoza), 6, $13,14,28,30,31$

Cavero, v. Pero

Darlael, v. Antón

Ezmel Azamel, Don, 15

Falçes, v. Martín

Fanlo, v. Gabriel

Felizes, v. Pero

Ferrández, v. Pero

Feyra, v. Miguel

Françés, En, (canónigo), 22

Françés d'Alagón, Don, 40

Gabriel de Fanlo, Mosén (baile), 9, 10

Garci Beltrán de Sabalça, 39

Garci Longares, 3, 19

García de Montanya, 5

Garci Pallaranco, 14

Gurrea, v. Pedro

Jacme Val, 37

Johan de De[¿?], 4

Johan de Moncayo, Don, 3, 14, 15, 19,38

Johan de Santa Cruç, Don, 6

Johan de Tonyá, Don, 3

Labí, v. Yehudá

Longares, v. Garci
Martín de Falçes, 4

Mes od, 29, y v. Yishac

Miguel de la Feyra (fiscal del rey), 21

Mirón, v. Šelomó

Moncayo, v. Johan

Montanya, v. García

Ortiz, v. Per

Pallaranco, v. Garci

Panplonés, v. Yom Tob

Pero Cavero, Don (lugarteniente del baile), 9,10

Pero Ferrández de Felizes, 7

Pedro de Gurrea, 7

Per Ortiz de Sabalça, 18, 27

Pero Ruíz d'Asín, Don, 3, 38

Rabiça, v. Šemuel

Rico, v. Yishac

Ruíz d'Asín, v. Pero

Sa'adiá, v. Yuçé

Sabalça, v. Garci Beltrán, Per Ortiz

Santa Cruç, v. Johan

Šelomó del Mirón, 15

Šemuel Abad, Don, 6

Šemuel ben La Rabiça, Rabí, 14

Šemuel Ben Ban Nist (Tudela), 36

Siçilia, (rey de) 23

Sobiça, v. Yénigo

Tolosana, Dona, 13

Tonyá, v. Johan

Tutela (Tudela), 36

Usillo, v.Yuçaf

Val, v. Jacme

Yehudá ben Labí, Don, 13

Yénigo de Sobiça, 14

Yishac Alcalhorrí, 6, 14

Yishac Mes od, 12

Yishac el Rico, 28

Yom Tob Panplonés, 26

Yuçaf ben Usillo, 13

Yuçé ben Sa ádiá, 20

\section{(Continuará)}




\section{RESUMEN}

Estudio introductorio con transcripción de los fragmentos de un registro contable de 1406 y 1407 de los pagos de la aljama de Tarazona (Aragón). Los cuarenta y dos cargos anotados en aljamía romance aragonesa, que incluye interesantes detalles léxicos, proporcionan información acerca de pagos realizados por oficiales de la aljama sobre asuntos diversos: fiscalidad y gastos de defensa de la aljama, su endeudamiento, el proceso y la ejecución de un malsín, gastos de sus instituciones religiosas y de asistencia social, sueldos de oficiales y pago por la aljama de las «cuatro especies» utilizadas en Sucot. Especialmente importantes son las referencias a la relación de dependencia respecto de la judería de Zaragoza.

PALABRAS ClAVE: Judíos, Aragón, Tarazona, siglo XV, aljama, contabilidad, malsín.

\section{SUMMARY}

Preliminary study and transcription of the surviving fragments of an expenditures' register of the Jewish community of Tarazona (1406-1407). The forty-two entries written in Aragonese aljamía deal with payments implemented by communal officers on different issues: fiscal disbursements, communal defence expenses and public debt, trial and execution of an informer, religious expenses (maintenance of buildings and charity institutions, officers' salaries, and payment of the Sukkot arba'ah minim). Especially relevant are the references to dependence relations regarding the Saragossa Jewish community.

KEYwORDS: Jews, Aragon, Tarazona, fifteenth century, Jewish community, accountability, Jewish informers. 